\title{
Komparasi Penerapan Bahasa Jurnalistik Portal Berita Daring Nasional
}

\author{
1Shara Oktaviani Alam, ${ }^{2}$ Kartini Rosmalah Dewi Katili \\ 1Universitas Islam ‘45' Bekasi \\ 2Universitas Islam '45' Bekasi \\ Email: ${ }^{1}$ sharaoktavia6@gmail.com; ${ }^{2 k r . i l k o m @ g m a i l . c o m ~}$
}

\begin{abstract}
Online news portals usually show latest news and can be accessed by anyone. Nevertheless, online news portals seem to pay less attention to journalistic writing conventions in writing their news. The present study aimed to analyse writing styles of two online news portals; Antaranews.com and Kompas.com. Several articles of those online news portals would be compared with journalistic writing conventions of Sumadiria. The present study used qualitative approach to analyse content and description of particular articles in those online news portals. The results suggest that $51 \%$ articles in Antaranews.com followed journalistic writing conventions whereas only $49 \%$ of articles in Kompas.com which were written according to journalistic writing conventions. The results indicate that both online news portals rarely write their news in simple and concise manner. Nevertheless, it may take more extensive study to prove the above point as each online news portal might have their signature styles to write their news.
\end{abstract}

\section{Keywords: journalistic language, content analysis, news, news portal}

\section{Pendahuluan}

Dunia jurnalistik saat ini semakin menunjukkan perkembangan yang pesat. Hal ini ditunjukkan dengan banyaknya media sebagai sarana untuk memperoleh hasil karya dari jurnalistik, yaitu berita. Di masa modern ini, masyarakat tidak hanya membutuhkan berita yang aktual, akurat, dan menarik, tetapi kecepatan perkembangan dalam pemberitaan juga dibutuhkan. Sarana media massa yang dapat memenuhi kebutuhan tersebut adalah media daring. Media yang membutuhkan jaringan internet ini biasa disebut portal berita daring (news portal) yang menjadi pilihan utama khalayak masa kini. Karena dalam pemberitaannya, media daring selalu mutakhir serta mudah diakses dimana saja dan kapan saja.

Pada setiap media pemberitaan, bahasa menjadi aspek utama untuk menyampaikan informasi. Penggunaan bahasa atau pemilihan kata-kata untuk menyusun kalimat berita pada setiap media pun berbeda. Bahasa ini menjadi tolak ukur masyarakat tertarik dan tetap membaca berita dari media tersebut atau tidak. Bahasa pada media daring pun tak luput dari perhatian pembaca. Bahasa dapat membangun sebuah representasi simbolis yang sangat besar dalam realitas kehidupan khalayak. Melalui bahasa, khalayak dapat memaknai tanda-tanda yang dituangkan dalam sebuah berita yang akhirnya membentuk representasi dari tanda yang dibaca dalam bentuk bahasa. 
Dengan demikian, bahasa menjadi instrumen utama yang berperan dalam representasi (Bungin, 2008: 17).

Di era yang teknologinya semakin canggih ini portal-portal berita daring semakin banyak membuat khalayak bebas memilih sumber mana yang akan dibaca. Bahasa menjadi salah satu yang khalayak perhatikan. Hal ini karena tidak semua pembaca memahami informasi apa yang disampaikan oleh portal berita tersebut sehingga menyebabkan multitafsir dan persepsi mengikuti pandangan portal berita yang dibaca. Tatanan bahasa jurnalistik yang tidak lepas dari Bahasa Indonesia ini dapat mencerminkan kredibilitas dari media pemberitaan itu sendiri.

Antaranews.com sendiri merupakan media yang berasal dari Perusahaan Umum Lembaga Kantor Berita (Perum LKBN) Antara. Perusahaan ini merupakan BUMN (Badan Usaha Milik Negara) yang ditugaskan untuk melakukan peliputan dan penyebarluasan informasi yang cepat, akurat, dan penting ke seluruh wilayah Indonesia dan dunia Internasional (www.antara.net.id).

Sedangkan, Kompas.com merupakan sebuah portal web yang berisi berita dan artikel daring di Indonesia. Berbeda dari situs-situs berita berbahasa Indonesia lainnya, Kompas.com hanya mempunyai edisi daring dan menggantungkan pendapat dari bidang iklan. Namun, Kompas.com merupakan yang terdepan dalam berita-berita baru (breaking news). Kompas.com menjadi bagian dari Kompas Gramedia (www.kompas.com). Fokus yang dijadikan sebagai objek adalah 31 berita dari rubrik Nasional edisi 1 Desember - 31 Desember 2017.

Sebagai penguat penelitian tentang Bahasa Jurnalistik, penuliti melihat penelitian Khairunnisa (2012) tentang berita utama "straight news" pada surat kabar Radar Bekasi. Khairunnisa menemukan bahwa di dalam satu berita straight news terdapat pelanggaran kaidah bahasa jurnalistik yaitu tidak jelas dan tidak padat. Pada Surat Kabar Harian Pagi Riau Pos (Azizah, 2013) juga ditemukan kesalahan-kesalahan dalam penerapan bahasa jurnalistik pada intro feature seperti penggunaan singkatan yang salah, tidak terlihatnya salah satu unsur $5 \mathrm{~W}+1 \mathrm{H}$ dalam feature, dan masih menggunakan kata yang mubazir dan pemborosan kata. Kemudian Futari (2016) juga menemukan adanya kesalahan bahasa jurnalistik pada Harian Kompas, yaitu pelanggaran pedoman bahasa jurnalistiknya seperti sederhana, singkat, padat, jelas, lugas, jernih, menarik, demokratis, populis, logis, dan gramatikal.

Berdasarkan latar belakang di atas, maka penelitian ini akan membahas mengenai perbandingan penerapan bahasa jurnalistik pada kedua portal berita tersebut. Penelitian ini menggunakan pendekatan kualitatif analisis isi. Dengan demikian, perumusan masalah pada penelitian ini adalah bagaimana perbandingan penerapan bahasa jurnalistik pada portal berita daring Antaranews.com dan Kompas.com? 
Berdasarkan rumusan masalah, maka tujuan dari penelitian ini adalah untuk menganalisis bagaimana per-bandingan penerapan penggunaan bahasa jurnalistik pada portal berita daring Antaranews.com dan Kompas.com.

\section{Kerangka Teori}

\section{Ejaan Bahasa Indonesia (EBI)}

Sebagai bahasa negara, bahasa Indonesia berfungsi sebagai bahasa resmi kenegaraan, bahasa pengantar di dalam dunia pendidikan, alat pengembangan kebudayaan, ilmu pengetahuan, teknologi, sebagai bahasa media massa, bahasa sastra Indonesia, dan bahasa yang memperkaya khazanah bahasa daerah (Arifin dan Tasai, 2014: 12-13).

Sebagai bahasa media massa, bahasa Indonesia harus menggunakan Ejaan Bahasa Indonesia (EBI) yang tepat. Berdasarkan Pedoman Umum Ejaan Bahasa Indonesia Edisi Keempat, terdiri dari penggunaan huruf kapital, huruf miring, gabungan kata, kata depan, singkatan dan akronim, penulisan angka, serta pemakaian tanda baca.

\section{Huruf Kapital}

Huruf kapital dipakai sebagai huruf pertama pada awal kalimat. Huruf ini juga dipakai sebagai huruf pertama unsur nama orang, termasuk julukan, jabatan, dan pangkat yang diikuti nama orang tersebut. Digunakan sebagai huruf pertama nama bangsa, suku bangsa, bahasa, negara, dan letak geografis. Selain itu, huruf kapital letakkan sebagai huruf pertama nama tahun, bulan, hari, dan hari besar.

2. Kata depan

Kata depan, seperti di, ke, dan dari, ditulis terpisah dari kata yang mengikutinya.

\section{Singkatan}

Singkatan terdiri dari beberapa bentuk. Singkatan nama orang, gelar, sapaan, jabatan, atau pangkat diikuti dengan tanda titik pada setiap unsur singkatan itu. Bentuk singkatan lainnya, terdiri dari huruf awal setiap kata nama lembaga pemerintah dan ketatanegaraan, lembaga pendidikan, badan atau organisasi, serta nama dokumen resmi ditulis dengan huruf kapital tanpa titik. Singkatan yang terdiri atas huruf awal setiap kata yang bukan nama diri ditulis dengan huruf kapital tanpa tanda titik.

\section{Penyusunan kalimat efektif}

Kalimat dalam ragam resmi, baik lisan maupun tertulis, harus memiliki subjek (S) dan predikat (P). Kalau tidak memiliki unsur subjek atau unsur predikat, pernyataan ini bukanlah kalimat, melainkan frasa. Kalimat adalah satuan bahasa terkecil, dalam wujud lisan atau tulisan, yang mengungkapkan pikiran yang utuh. Dalam wujud tulisan berhuruf latin kalimat dimulai dengan 
huruf kapital dan diakhiri dengan tanda titik (.), tanda tanya (?), atau tanda seru (!). Struktur kalimat yang tepat terdiri dari subjek (S), predikat (P), objek $(\mathrm{O})$, dan keterangan $(\mathrm{K})$.

5. Penggunaan tanda baca

\section{a. Penggunaan Tanda Titik}

Sebagai akhir pada kalimat dan sebagai pemisah angka penunjuk waktu

b. Penggunaan Tanda Koma

Digunakan sebagai penghubung kata, pemisah antara anak kalimat yang mendahului induk kalimat, penghubung antar kalimat, pemisah antara kalimat dan petikan langsung, digunakan pada angka desimal, dan pemisah antara nama dan jabatan seseorang.

6. Penggunaan Tanda Hubung

Tanda hubung digunakan untuk merangkai kalimat maupun kata, merangkai dua nama orang, jabatan atau lembaga, dan digunakan sebagai pengganti kata “antara” dan “sampai dengan” Kemendikbud, 2016: 5-49).

\section{Bahasa Jurnalistik}

Bahasa jurnalistik didefinisikan sebagai bahasa yang digunakan oleh para wartawan, redaktur, atau pengelola media massa dalam menyusun dan menyajikan, memuat, menyiarkan dan menayangkan berita serta laporan pristiwa atau pernyataan yang benar, aktual, penting dan atau menarik dengan tujuan agar mudah dipahami isisnya dan cepat ditangkap maknanya (Sumadiria, 2008: 7).

Menurut pakar bahasa terkemuka dari Bandung JS Badudur, bahasa jurnalistik harus singkat, padat, sederhana, jelas, lugas, tetapi selalu menarik. Sifat-sifat itu harus dipenuhi oleh bahasa jurnalistik mengingat media massa dinikmati oleh lapisan masyarakat yang tidak sama tingkat pengetahuannya. Orang tidak harus menghabiskan waktunya hanya untuk membaca surat kabar. Harus lugas, tetapi jelas, agar mudah dipahami. Orang tidak perlu mesti mengulang- ulang apa yang dibacanya karena ketidakjelasan bahasa yang digunakan dalam surat kabar itu (Sumadiria, 2008: 6-7).

Menurut AS Haris dalam bukunya yang berjudul Bahasa Jurnalistik (Panduan Praktis Penulis dan Jurnalistik), terdapat 17 ciri bahasa jurnalistik yakni sederhana, singkat, padat, lugas, jelas, jernih, menarik, demokratis, populis, logis, gramatikal, menghindari kata tutur, menghindari kata dan istilah asing, pilihan kata (diksi) yang tepat, mengutamakan kalimat aktif, sejauh mungkin menghindari penggunaan kata atau istilah-istilah teknis, dan tunduk kepada kaidah etika (Sumadiria, 2005:53-61).

1. Sederhana

Sederhana berarti selalu mengutamakan dan memilih kata atau kalimat 
yang paling banyak diketahui maknanya oleh khalayak pembaca yang sangat heterogen. Contoh dari kalimat sederhana yaitu: Pemerintah perlu merubah drastis kelembagaan dan tata kelola penyelenggaraan haji agar kualitas pelayanan publik bagi jemaah dapat meningkat.

Kata "merubah drastis" sebenarnya dapat diubah menjadi "reformasi", namun kata "merubah drastis" lebih sederhana dan lebih banyak diketahui oleh khalayak.

2. Singkat

Singkat berarti langsung kepada pokok masalah (to the point), tidak bertele-tele, tidak berputar-putar, tidak memboroskan waktu pembaca yang sangat berharga. Contoh kalimat singkat yaitu:

Tersangka menculik korban saat jam pulang sekolah.

\section{Padat}

Menurut Patmono SK, redaktur senior Sinar Harapan dalam buku Teknik Jurnalistik (1996:45), padat dalam bahasa jurnalistik berarti sarat informasi. Contoh kalimat padat yaitu:

Namun, disaat harga sayur mayur turun harga, telur ayam justru mengalami kenaikan, dari harga sebelumnya Rp18.000 sampai Rp20.000 per kilogram, sekarang mencapai harga Rp22.000 per kilogram.

\section{Lugas}

Lugas berarti tegas, tidak ambigu, sekaligus menghindari eufemisme atau penghalusan kata dan kalimat yang bisa membingungkan khalayak pembaca sehingga terjadi perbedaan persepsi dan kesalahan konklusi. Kata yang lugas selalu menekankan pada satu arti serta menghindari kemungkinan adanya penafsiran lain terhadap arti dan makna kata tersebut. Contoh kalimat lugas yaitu: Tersangka membunuh korban dengan cara menembak dada korban.

5. Jelas

Jelas berarti mudah ditangkap maksudnya, tidak baur dan kabur. Jelas disini mengandung tiga arti yaitu, jelas artinya, jelas susunan kata atau kalimatnya sesuai dengan kaidah subjek-predikat-objek-keterangan (SPOK), jelas sasaran atau maksudnya. Contoh kalimat jelas adalah:

\section{Pelaku meracuni korban dengan sianida}

$\begin{array}{llll}S & P & O & K\end{array}$

6. Jernih

Jernih berarti bening, tembus pandang, transparan, jujur, tulus, tidak menyembunyikan sesuatu yang lain yang bersifat negatif seperti prasangka atau fitnah. Dalam pendekatan analisis wacana, kata dan kalimat yang jernih berarti kata dan kalimat yang tidak memiliki agenda tersembunyi dibalik 
pemuatan suatu berita atau laporan kecuali fakta, kebenaran, kepentingan publik. Contoh kalimat jernih adalah: "Gubernur non-aktif DKI Jakarta diduga menistakan agama."

7. Menarik

Menarik artinya mampu meningkatkan minat dan perhatian khalayak pembaca, memicu selera baca, serta membuat orang tertidur, terjaga seketika. Bahasa jurnalistik berpijak pada prinsip: menarik, benar, dan baku. Contoh kalimat menarik adalah: "Polisi mengamankan keluarga keraton terkait kasus penipuan."

8. Populis

Populis berarti setiap kata, istilah, atau kalimat apapun yang terdapat dalam karya-karya jurnalistik harus akrab di telinga, di mata dan di benak pikiran khalayak pembaca, pendengar, atau pemirsa. Bahasa jurnalistik harus merakyat, artinya dan diakrabi oleh semua lapisan masyarakat. Contoh kalimat populis adalah:

"Pendataan ini juga bagian dari upaya menekan angka kriminalitas."

\section{Gramatikal}

Gramatikal berarti kata, istilah, atau kalimat apa pun yang dipakai dan dipilih dalam bahasa jurnalistik harus mengikuti kaidah tata bahasa baku.

Bahasa baku berarti bahasa resmi sesuai dengan ketentuan tata bahasa serta pedoman ejaan yang disempurnakan berikut pedoman pembentukan istilah yang menyertainya. Contoh kalimat gramatikal yaitu:

"Ia mengatakan, presiden menyetujui anggaran pendidikan dinaikan menjadi 25 persen dai total APBN dalam lima tahun ke depan."

10. Menghindari kata dan istilah asing

Berita ditulis, dibaca, atau didengar yang harus mengetahui arti dan makna setiap kata yang dibaca dan didengarnya. Jika berita diselipi kata- kata asing menjadikan berita itu tidak informatif dan komunikatif dan juga sangat membingungkan. Menurut teori komunikasi, khalayak media massa anonim dan heterogen. Dalam perspektif teori jurnalistik, memasukkan kata atau istilah asing pada berita yang kita tulis, kita udarakan atau kita tayangkan. Contoh kalimat yang menghindari kata dan istilah asing yaitu:

"Acara tersebut dihadiri Menteri Pendidikan."

\section{Metode Penelitian}

Metode yang digunakan dalam penelitian ini adalah kualitatif. Metode penelitian kualitatif adalah penelitian yang menghasilkan data deskriptif berupa kata-kata tertulis ataupun lisan dari orang-orang dan perilaku yang diamati oleh peneliti (Moleong, 2011: 4). Dalam penelitian ini, peneliti 
menggunakan pendekatan kualitatif dengan analisis isi.

Analisis isi adalah teknik penelitian untuk membuat inferensi-inferensi yang dapat ditiru, dan sahih data dengan memperhatikan konteksnya. Analisis isi disini menggunakan angka-angka di dalam tabel koding yang selanjutnya akan diproses dengan menggunakan angka persentase.

Teknik pengumpulan data merupakan cara-cara yang dapat digunakan oleh peneliti untuk mengumpulkan data- data yang mendukung penelitian. Teknik pengumpulan data yang tepat akan memungkinkan peneliti memperoleh hasil penelitian yang valid (Kriyantono, 2006: 95). Dalam sebuah penelitian, data dapat dibedakan menjadi dua berdasarkan sumbernya, yaitu primer dan sekunder.

Data primer adalah data yang dikumpulkan sendiri oleh peneliti langsung dari sumber pertama atau tempat objek penelitian dilakukan (Siregar, 2013: 16). Dalam hal ini, peneliti menggunakan cara observasi, yaitu teknik pengumpulan data dalam penelitian ini pun sama terdiri dari wawancara dan observasi. Dalam tahap observasi, peneliti mengumpulkan data-data yang diperlukan. Penulis mengumpulkan berita-berita yang ada di antaranews.com pada edisi 1 Desember 2017- 31 Desember 2017.

Data sekunder dalam penelitian ini diperoleh dari penelitian terdahulu berupa jurnal, buku-buku, dan lain sebagainya yang selaras dengan penelitian ini. Peneliti menyusun kategorisasi atau indikator dari variabel penelitian untuk menganalisis berita-berita yang dipilih. Indikator ditentukan dengan mempelajari, mendalami, dan mengutip teori-teori atau konsep dari sejumlah literatur, baik buku, jurnal atau karya tulis lain yang relevan dengan topik peneliti.

\section{Hasil dan Pembahasan}

Pada penelitian ini, peneliti memaparkan hasil penelitian dari masalah pokok yang menjadi bahan penelitian, yaitu penerapan Ejaan Bahasa Indonesia (EBI) dan bahasa jurnalistik dalam berita yang ada pada portal berita Antaranews.com dan Kompas.com edisi 1 Desember - 31 Desember 2017. Hasil pada penelitian ini didapat dari data berupa angka hasil tabel koding dan narasumber yang ada selaku informan sebagai pendukung dari penelitian ini. Penelitian ini dilakukan berdasarkan pada lima indikator EBI huruf kapital, singkatan, kata depan, penggunaan kalimat efektif dan tanda baca sebagai pondasi dari bahasa. Kemudian, menganalisis penggunaan 10 indikator bahasa jurnalistik berdasarkan AS Haris Sumadiria.

Dengan melalui analisis yang dilakukan peneliti, telah didapat persentase pengunaan EBI pada 31 berita dari kedua portal tersebut. Total penerapan indikator EBI pada Antaranews.com sebesar 4781. Penerapan dari kelima indikator EBI yang benar dan efektif sebesar 4517 atau dengan 
persentase 96\%, sedangkan yang tidak menerapkan sebesar 264 dengan persentase $4 \%$. Jumlah penerapan indikator bahasa jurnalistik pada Antaranews.com sebesar 231 dengan persentase $51 \%$. Pada 31berita yang ada di Kompas.com diedisi tersebut, total penerapan indikator EBI sebesar 4356. Penerapan kelima indikator yang benar dan efektif sebesar 4035 dengan persentase $93 \%$, sedangkan sebaliknya yang tidak diterapkan dengan baik dan benar sebesar 321 dengan persentase 7\%. Pada bahasa jurnalistik, penerapan indikator yang benar dan efektif sebesar 221 dengan persentase $49 \%$.

Pada penerapan EBI, banyak ditemukan kesalahan penempatan tanda baca titik (.) dan koma (,). Pengunaan kalimat majemuk bertingkat pun juga membuat pembaca bingung akan isi berita. kalimat yang seharusnya bisa menjadi dua bahkan tiga kalimat, hanya dibuat menjadi satu kalimat demi menyingkat isi berita. Selain itu, kesalahan dalam penyusunan kalimat efektif (SPOK) yang tidak diperhatikan pembaca, tetapi tidak sesuai dengan kaidah EBI. Dalam konteks Ejaan Bahasa Indonesia, Antaranews.com masih lebih unggul dengan persentase $96 \%$ dibandingkan Kompas.com dengan persentase 93\%.

Pada 10 indikator bahasa jurnalistik, ada tujuh indikator yang jarang bahkan tidak ditemukan dalam berita, yaitu sederhana, singkat, padat, lugas, jelas, jernih, dan menarik. Keenam indikator tersebut saling berkaitan satu sama lainnya. Menurut salah satu ahli dalam bidang bahasa jurnalistik, Zulkarnain Alfisyahrin mengatakan, membaca berita itu harus seperti minum kopi. Saat masuk mulut, dengan mudah kopi itu melewati kerongkongan hingga sampai ke perut. Begitupun membaca berita, harus lugas atau tidak bias makna yang bisa membuat pembaca berpikir bukan langsung mendapatkan informasi. Berita harus jelas, tidak membuat pembaca menerka. Berita pun harus jernih, transparan akan sumber informasinya. Berita tidak boleh berputar-putar, menggunakan kalimat majemuk bertingkat, penggunaan kalimat klausa terlalu banyak yang bisa membuat multitafsir.

Indiktor yang tidak ditemukan lainnya adalah menarik. Menarik disini bukanlah nilai berita, tetapi kata atau kalimat yang membuat pembaca tertarik untuk membaca berita tersebut. Biasanya kalimat atau kata itu tidak terdapat dalam KBBI (Kamus Besar Bahasa Indonesia), namun kata atau kalimat itu masuk ke dalam kategori indikator gramatikal atau sesuai dengan bahasa baku jurnalistik. Contoh kata menarik antara lain "mengangkangi" yang mempunyai arti dari melanggar peraturan atau ketentuan dan "menggenjot" diartikan sebagai penekanan atau memacu dengan cepat.

Selain dari segi bahasa, hal lain yang termasuk dalam bahasa jurnalistik antara lain keseragaman dan konsistensi penggunaan bahasa jurnalistik. Penggunaan huruf kapital Antaranews.com memiliki 
keseragaman yang lebih baik daripada Kompas.com. Hal tersebut terlihat dari penulisan judul yang penulisannya menggunakan huruf kecil dan kapital pada awal kalimat judul dan kata-kata yang memang diharuskan menggunakan huruf kapital. Pada Kompas.com masih ada ketidakseragaman dalam penggunaan huruf kapital. Masih ditemukan ketidakseragaman dari penulisan judul sampai bagian beritanya. Pada penulisan judul, Kompas.com menulis setiap kata dengan huruf kapital. Namun, ada kata yang seharusnya menggunakan huruf kapital namun ditulis dengan huruf kecil. Ini menandakan ketidakseragaman antar penulis berita.

Keseragaman juga dilihat dari penulisan angka. Dalam bahasa jurnalistik, jika angka di bawah 10 ditulis dengan huruf, seperti 9, 8, 7, dan seterusnya. Jika angka di atas 10 ditulis menggunakan angka juga, seperti 11, 12, dan seterusnya. Biasanya, penulisan seperti ini sering salah dalam berita walaupun sudah menjadi hukum umum yang diketahui jurnalis dalam penulisannya. Kedua portal berita masih kurang efektif dalam menerapkannya. Pada keseragaman alinea atau paragraf, berita yang ada di Antaranews.com dan Kompas.com, peneliti melihat adanya keseragaman pada penulisan berita khususnya alinea. Keseragaman itu akan mempercantik tampilan berita yang akan disuguhkan kepada pembaca. Walaupun ruang penulisan pada media daring tidak terbatas, tetapi keseragaman alinea tetap menjadi perhatian.

\section{Perbandingan Penerapan Bahasa Jurnalistik}

Perbandingan bahasa jurnalistik yang mengarah pada indikator yang tidak ditemukan dalam berita, Antaranews.com dan Kompas.com memiliki perbedaan yang sangat tipis. Keduanya sama-sama masih kurang menerapkan poin sederhana, singkat, padat, lugas, jelas, jernih, dan menarik. Namun, Antaranews.com masih lebih unggul dalam menerapkannya.

Perbandingan dari segi keseragaman dalam penulisan berita di kedua media, Antaranews.com masih lebih unggul dibandingkan Kompas.com. Dari segi penggunaan huruf kapital dalam judul, Antaranews.com lebih konsisten daripada Kompas.com yang masih belum konsisten dalam pengunaan huruf kapital pada judul maupun isi berita.

Perbandingan dalam segi penulisan angka, keduanya masih belum konsisten. Masih ditemukan penulisan angka di bawah 10 dengan angka, bukan huruf seperti seharusnya. Keduanya harus lebih teliti, tertib, dan konsisten dalam hal ini.

Perbandingan dalam segi alinea atau paragraf, Antaranews.com lebih baik dibandingkan Kompas. Memang masih terlihat penulisan per satu alinea yang terlalu panjang di keduanya. Tetapi, jika dilihat dari keseluruhan, Antaranews.com lebih rapi dan teratur dalam mengelola alinea dibandingkan Kompas.com. Berdasarkan data dan hasil wawancara yang 
dilakukan, Antaranews.com merupakan media yang penerapan bahasa jurnalistiknya lebih baik dari Kompas.com diikuti dengan jumlah persentase yang ada di dalam gambar yang telah ditampilkan sebelumnya. Meskipun masih banyak ditemukan kesalahan dalam bahasa jurnalistik yang mengacu pada buku A.S Haris, kembali lagi kepada masing-masing medianya.

Karena setiap media memiliki, peraturan dan teknik menulis berita yang diatur dalam "buku putih" sebagai acuannya dan tidak mungkin sama dengan media lainnya. Hal itu mungkin disalahkan dari pandangan seorang yang mengerti dibidang jurnalistik, namun tidak disalahkan jika dilihat dari sudut pandang media itu sendiri yang diterapkan kepada, wartawan, redaktur, dan orang-orang yang berada didalamnya. Hal yang terpenting harus diperhatikan adalah pembaca mudah mengerti informasi yang ada di dalamnya, tidak berpikir dalam membaca berita, dan tidak salah mengerti isi didalamnya.

\section{Kesimpulan}

Berdasarkan hasil penelitian dan analisis yang telah peneliti lakukan, disimpulkan terkait perbandingan penerapan bahasa jurnalistik pada portal berita daring Antaranews.com dan Kompas.com. Hasil yang didapatkan berbanding sangat tipis. Dari segi persentase, selisih yang didapatkan hanya $2 \%$ dari total keduanya. Antaranews.com memiliki persentase sebesar $51 \%$, sedangkan Kompas.com memiliki persentase sebesar 49\%. Hasil yang didapatkan, indikator yang banyak tidak ditemukan pada berita di kedua media tersebut ada enam, yaitu sederhana, singkat, padat, lugas, jelas, jernih dan menarik.

a. Pada portal berita Antaranews.com dan Kompas.com tidak ditemukan indikator sederhana, singkat, dan padat. Hal itu membuktikan berita yang ada tidak efektif dan tidak memenuhi indikator bahasa jurnalistik.

b. Peneliti juga tidak menemukan penerapan indikator lugas, jelas, dan jernih pada berita yang dijadikan objek. Indikator tidak efektif dan ditemukan karena masih ada kalimat ataupun kata yang membuat pembaca berpikir saat membaca berita.

c. Indikator lainnya yang jarang ditemukan didalam berita-berita tersebut adalah menarik. Dalam berita yang diteliti, hanya ditemukan masingmasing media satu kata unik seperti "mengangkangi" dan "menggenjot".

d. Keseragaman dalam penulisan berita di media antara lain penggunaan huruf kapital, penulisan angka, dan alinea atau paragraf. Pada keseragaman penggunaan huruf kapital, Antaranews.com lebih unggul karena lebih konsisten dalam menerapkannya pada judul maupun isi 
berita dibandingkan Kompas.com yang masih belum konsisten dalam menerapkannya di judul maupun isi. Pada penulisan angka, kedua portal berita sama-sama masih belum konsisten karena masih menulis angka dibawah 10 dengan angka bukan dengan huruf seperti seharusnya. Dalam keseragaman pada alinea, Antaranews.com lebih unggul karena jika dilihat dari keseluruhan terlihat lebih rapi dengan komposisi alinea yang tidak jauh berbeda jumlahnya. Sedangkan pada Kompas.com masih ditemukan satu alinea dengan satu kalimat yang pendek. Komposisi antar aline tidak rapi dan jauh jumlah kalimatnya.

Dari keseluruhan perbandingan yang peneliti lakukan, kembali kepada kaidah atau aturan setiap media. Setiap media memiliki aturan penulisan atau biasa dikatakan dalam dunia jurnalistik dengan pedoman atau buku putih. Dalam pedoman itulah semua peraturan untuk berita dan penulisannya diatur sesuai kriteria media itu sendiri, karena pastinya setiap media memiliki ciri khas untuk dapat membedakannya.

\section{Daftar Pustaka}

Arifin, E Zainal dan S Amran Tasai. 2014. "Bahasa Indonesia: Sebagai Mata Kuliah Pengembangan Kepribadian". Tangerang: Pustaka Mandiri.

Aryani, Rahmadita. 2011. "Konsep Penyajian Jurnalisme Online Di www.Antaranews.com". Skripsi. Universitas Syarif Hidayatullah Jakarta.

Azizah, Anisa. 2013. "Penerapan Bahasa Jurnalistik Pada Intro Feature di Surat Kabar Harian Pagi Riau Pos". Skripsi. Universitas Islam Negeri Sultan Syarif Kasim Riau.

Badan Pengembangan dan Pembinaan Bahasa, Kementerian Pendidikan dan Kebudayaan 2016. "Pedoman Umum Ejaan Bahasa Indonesia".

Bungin, Burhan. 2008. "Konstruksi Sosial Media Massa". Jakarta : Kencana.

Bungin, Burhan. 2007. "Penelitian Kualitatif: Komunikasi, Ekonomi, Kebijakan Publik, dan Ilmu Sosial Lainnya". Jakarta: Kencana Prenada Media Group

Eriyanto. 2011. "Analisis Isi : Pengantar Metodologi untuk Penelitian Ilmu Komunikasi dan Ilmu-Ilmu Sosial Lainnya". Jakarta : Kecana Prenada Media Group.

Futari, Hana. 2016. "Konsistensi Harian Kompas Dalam Mengimplementaskan Bahasa Jurnalistik". Skripsi. Universitas Islam Negeri Syarif Hidayatullah Jakarta.

Khairunnisa, Eneng. 2012. "Penerapan Bahasa Jurnalistik Pada Berita Utama "Straight News" Di Surat Kabar "Radar Bekasi" Edisi 1-5 Oktober 2012". Skripsi. Universitas Islam Negeri Syarif Hidayatullah Jakarta.

Kriyantono, Rachmat. 2006. “Teknik Praktis Riset Komunikasi”. Jakarta: Kencana Praenadamedia Group. 
Moleong, j, Lexy. 2006. "Metodologi Penelitia Kualitatif". Bandung: PT. Remaja Rosdakarya

Novienty, Yayan. 2017. "Analisis Representasi Perempuan Dalam Koran Kuning". Skripsi. Universitas Islam 45 Bekasi.

Rahmah. 2016. “Analisis Penerapan Bahasa Jurnalistik Terhadap Berita Kriminal Tribun Timur". Skripsi. UIN Alauddin Makassar.

Siregar, Syofian. 2013. "METODE PENELITIAN KUANTITATIF: Dilengkapi Perbandingan Perhitungan Manual E SPSS Edisi Pertama.

Sumadiria, AS Haris. 2008. "Bahasa Jurnalistik: Panduan Praktis Penulis $\mathcal{E}$ Jurnalistik". Bandung : Simbiosa Rekatama Media.

Syamsul, Asep dan M Romli. 2009. “Bahasa Media : Panduan Praktis Bahasa Jurnalistik". Bandung : Batic Press.

Virlanda, Bella. 2014. "Analisis isi penggunaan bahasa jurnalistik pada berita di website universitas lampung (studi pada berita periode November- desember 2014)". Skripsi. Universitas Lampung.

www.antaranews.com

www.antara.net.id

www.kompas.com 